\begin{tabular}{c} 
Volume and Issues Obtainable at Center for Sustainability Research and Consultancy \\
Journal of Business and Social Review in Emerging Economies \\
ISSN: 2519-089X (E): 2519-0326 \\
Volume 6: No. 3, 2020 \\
JSRᄃ \\
Journal homepage: www.publishing.globalcsrc.org/jbsee \\
\hline
\end{tabular}

\title{
The Dawn for a New Antitrust Law Framework for Digital Platforms, Evidence from an Empirical Comparative Analysis of EU Antitrust Decisions
}

\author{
${ }^{1}$ Shahzada Aamir Mushtaq, ${ }^{2}$ Fariha Sabahat, ${ }^{3}$ Huma Rao \\ ${ }^{1}$ School of law and Economic, Zhengzhou University, Henan, China, aamir.adv@gs.zzu.edu.cn \\ ${ }^{2 \& 3}$ Department of Political Sciences, Institute Of Social Sciences, Bahauddin Zakariya University Multan, Pakistan, \\ fia_saba@hotmail.com, humarao15@gmail.com
}

\begin{abstract}
ARTICLE DETAILS
History

Revised format: August 2020

Available Online: September 2020
\end{abstract}

\section{Keywords}

Digital Markets, Big Data,

Competition Law, Digital

Platforms, Data Protection and

Privacy

\section{JEL Classification}

MO, M1

\begin{abstract}
The Digital platforms are a unique creation of the late 20th and early $21 \mathrm{st}$ centuries. The digital economy may have replaced the industrial economy, but the rules created to oversee the fair operation of the industrial economy have not kept pace with that evolution. The digitalization of the economy with consumer data as a new critical resource is an advancement of a technological revolution which needs an adaptation of regulatory framework for markets and the world economy. This paper analyzed the privacy and data protection concerns in the digital economy from an economic perspective of small and medium-sized enterprises. The tech giants, by controlling user's data are exploiting it for their own commercial benefits and inflicting the threats to the privacy of users. This paper intends to shed light that it's not enough to look for policy solutions only within the competition or data protection law. Rather an integrated move from various regulatory perspectives is necessary. Therefore, the article focuses that the formalistic approach to article 101 and 102 of TFEU (Treaty On The Functioning OF The European Union which the EU Commission usually adopted as an effects-based approach) to counter exploitative, exclusionary practices, and potential harm to consumers is efficacious to regulate the digital platforms. Furthermore, this research presses the necessity of how the abusive conduct of data-driven entrants be regularized by forwarding the new concepts of antitrust law and its effective enforcement across the globe. The digital platforms have fundamentally changed the ways we interact with news, with each other, and with governments and business. Digital platforms act as intermediaries which connect two or more market participants via the platform and simplify their interaction.
\end{abstract}

\section{OPEN ACCESS}

(C) 2020 Center for Sustainability Research and Consultancy Pakistan under a Creative Commons Attribution-NonCommercial-ShareAlike 4.0

Corresponding author's email address: aamir.adv@gs.zzu.edu.cn

Recommended citation: Mushtaq, S. A., Sabahat, F. \& Rao, H. (2020). The Dawn for a New Antitrust Law Framework for Digital Platforms, Evidence from an Empirical Comparative Analysis of EU Antitrust Decisions. Journal of Business and Social Review in Emerging Economies, 6(3), 959-974 


\section{Introduction}

The parturient move of digital transformation, the concentration on big data, has triggered economic markets of digital firms resultantly raises key concerns about their dominance and its abuse for purely commercial gains contrary to the spirit of competition law. The conventional economic and antitrust theories seems to be the house of cards to ensure the economic growth and stability from the network externalities and the exploitative effects of market dominated firms in utilizing the customer's data. The jurisprudence of dominance and its abuse as laid down in Article 102 (TFEU) the Treaty of Functioning in European Union followed as basic guideline and precedent among almost all the European jurisdictions. Nuccio and Guerzoni, (2018) explores that few global players are taking the competitive advantage in the use of big data due to supra-national nature of their structure.

Yingzhi and Peng, (2019) identifies that data rich firms have become growingly active in measuring the consumer data and analyze market conditions for better performance and high profits. Sobot, (2018), explains that the lengthy and time taking judicial process is main impediment and also aggravate the already pregnant situation in regard to compliance of antitrust provisions. It further elaborated the historical Intel case in which European Commission (EC) fined Intel up to 1.06 billion Euro for abusing its dominant position by granting exclusivity rebates in 2009 . In 2014 the European General Court (EGC) upheld the EC decision and finally in 2017 the Court of Justice of European Union (EJEU) set aside the verdict of the General Court and remand the case to reconsider the framing of issues of exclusivity rebates and its potential effects on competition. The theoretical foundation of dominance and its abuse as enacted in Article 102 of TFEU and Article 54 of the European Economic Area (EEA) is of objective one, but the EC had always inflicted fines on alleged violations against ascendant firms relying on tests based effects in the market, although the velocity of those tests had been questioned many times at the appellate forum and no conduct yet be declared by the Commission as PER SE illegal. Moreover, certain business practices surfaced that has been characterized by facts as Per Se illegal on which we shed light in the fifth part. Many jurisdictions in Europe and some might be in Asia and Africa takes the European Commission guidelines and judicial interpretations of the Article 102 of TFEU as milestone, like in the TINE case from 2011, in which the Norwegian Supreme Court confirmed that the notion of abuse under section 11 of the Norway Competition Act mirrors the article 102 of the TFEU (NCA's decision).

In its landmarked judgment on 2017-6-22 the Norwegian Supreme Court had declined the appeal of two taxi companies against the findings of the Appellate Court which upheld the stance taken by the Norwegian Competition Authority(NCA) concerning the submission of joint bids in tender procedures (Retrieved from. https://konkurransetilsynet.no/?lang=en\&s=taxi+case+2017). The principle established by the Norwegian Top Court concludes in the following manner,

"The National Competition Authority (NCA) had concluded that the two taxi companies were actual and potential competitors in the same market and their submission of joint bids established restrictions on competitive process and competition by object which infringed the provisions of the Norwegian Competition Act."

In assessing the conduct whether it is abusive or not almost all jurisdictions in Europe have unanimously adopted the common approach concerning the relation between dominance and abusive practice is not mandatory except in Austria, where the Austrian Supreme Court has taken more aggressive instance on the abuse of dominance (Supreme Cartel Court in Fachverb and Reiseburos Vs Lufthansa). The Austrian Supreme Cartel Court in determining the abusive practice of dominant firms primarily raised some procedural issues namely, (a) presumptions for dominance, (b) rules on the burden of proof with respect to predatory pricing. The proponents of more economic approach (MEA) about the enforcement of competition law at EU level widely criticized the specific assessments of competition law regarding effects based approach. The European Commission has taken into account the constructive criticism, on the other hand the European courts are also seems incredulous about interpreting the violations under Article 102 of TFEU keeping in view the effects based doctrine.

In recent past the European Commission's decision against Google search also conventionally relies on the effects based approach while the courts have postulated that the tests which has been conducted to judge the velocity of anti competitive effects are not conclusive and in many European jurisdictions the Appellate courts or Tribunals remanded 
the case to the court of pecuniary jurisdiction to reframe the issues on concrete grounds concerning anti-competitive effects. The discrepancy between the Commission's effects based approach and the European courts dissenting view on it basically questioned the efficacious enforcement of competition statutes (Koenig, 2018).

Pinar Akman (2019) quoted that Google actually violates the antitrust law severely by applying various types of exclusivity conditions demanding the pre-installation of Google search app and its browser app which the regulatory authorities must be considered as per se illegal due to its direct harm to competitive process.

The Google's conduct in the case of android mobile devices and Google's search with the express conditions of tying and the provision of incentives to network operators and device manufacturers were to be taken by the Commission as Per Se prohibition because the nature of conditions does not need to be proved through tests and effects rather these are illegal on its face. Moreover, the Commission might have derived the principles from the famous case of Microsoft (decision no,2006-042, Feb 24 ${ }^{\text {th }}$ 2006) in which the Korean Fair Trade Commission (KFTC) sanctioned the Microsoft for tying with windows server operators and windows media service. In both the decisions (which have been taken by the EC and KFTC against Google and Microsoft respectively) nothing concrete had been established against the abusive practice of corporate tycoons on alleged violations of tying and loyalty rebates.

The difference between the Commission's and European courts approach in determining the liability of abusive conduct under Article 102 of TFEU is also evident from the fact which was ruled by European Court of Justice that it could be said to be abuse of dominant position where the practice in the market (market here means geographical market) is distinct from the dominated market bring effects on that distinct market in TETRA PAK II case. According to the concept contained in Article 102 of TFEU is that the link between dominance and abuse is not necessary while the European Court of Justice required the compulsory nexus between the two. In the market based economies the big participants having big data are frequently traded that data for different commodities due to which the challenge of data monopoly has reached its peak. The tale has not ended here, the big and dominant players with the use of different technological tools like, machine learning, artificial intelligence, algorithms, have deliberately trying to maintain or strengthen their monopolies, now the inevitable change is the call of time to balance economic efficiency and competitive growth (Dongwon, 2018).

Globally the regulators and researchers are making new proposals keeping in view mainly the exploitative and exclusionary abuses and it is also an axiomatic fact that legal theories of exploitative abuses mostly developed in Europe. The praiseworthy decision taken by the European Union Court of Justice with the observation that every exploitative abuse needs to be proved beyond the shadow of doubt with cogent evidence in MEO in April 2018. Further it is also explored by the European Court that effects based approach (which is currently in practice under article 102 of TFEU in across Europe) may distort the competition regime within the region (Choi, 2018).

The conventional rebates affects the competition in the same way as price reductions because the philosophy of competition law is that it aims to safeguard the competition law itself not the competitors. If the big firms offers a rebate with the intention to exclude rival competitors and restrict competition it embraces the illegality because attempt has been placed to maintain or strengthen their dominance and directly hits the basic concept of competition law (Choi, 2017).

Today seven out of the ten most profitable firms are tech organizations, with five situated in the US and two in China. They are: Apple (worth $\$ 927$ billion), Amazon ( $\$ 778$ billion), Alphabet (the holding organization for Google, worth $\$ 766$ billion), Microsoft (\$751 billion), Facebook ( $\$ 542$ billion), Ali-baba (the 'Chinese Amazon', \$499 billion) and Tencent (the 'Chinese Facebook', $\$ 491$ billion), with a joined market capitalization of $\$ 4.75$ trillion.

The FTC(federal trade commission) report shows that Google established a list of rival shopping sites in order to put those general search results artificially lower to take the business advantage and the report also contain the fact that Google users' liked the quality of rival shopping sites and dislikes the changes proposed by the Google.

Algorithms may overcome the issue of correlation vs causation, (Mattiuzzo, 2019), all over the world a new critical 
discussion has emerged about the concentration tendencies in the digital economy and the market power of large digital firms and platforms (Kerber, 2019). Big data has a very important role in the digital economy, because firms have accurate tools to collect, store, analyze, treat, monetize and disseminate voluminous amounts of data (Pfeiffer, 2019) digital environment causes objective detriment to consumers and undermines the competitive process (Kemp, 2019).

Gary Reback (2017) stated that earlier in 2007, if any user searched any product on Google, the price lists of other sites would simultaneously appear alongside the Google's general search results and were placed in ranks according to their quality to users. These "comparative shopping sites" were intended to recognized traders with the minimum prices. Therefore, these sites were ranked because of their accuracy and comprehensiveness of results and solely on that principle attracts maximum number of customers. Gradually comparative shopping sites became successful which perceived by Google as nascent threat to its designed plan to earn undue profits irrespective of causing intentional harm to competition and reduced the customer's choice. Moreover, as Google earn much of its profit through ads so, developed a "DECEPTIVE PLAN" to counter it, and this fact is also mentioned by the Federal Trade Commission (FTC) of the USA in his official report, a part of which was published in 2015 by the Wall Street Journal.

As Japan Fair Trade Commission (JFTC) highlighted the fact that the role of "Big Data" would accelerate the innovation around the industrial boundaries in connection with the advancement of Artificial Intelligence (AI) and Internet of Things (IOT). This will also affect industrial productivity and may constitute "fourth industrial revolution" So, this element would influence global economies and the sustainable business environment across the world, hence, needs aggressive regulatory framework and compliance efficiency. It is expected that big enterprises in production and manufacturing industry would utilize that customers data for their economic gains or to strengthen their market position as inputs. Therefore, data and its commercial employment in market activities is the matter of grave concern for conventional competition tools and regulatory regime.

Very recently The Australian Competition and Consumer Commission (ACCC) has commenced the "Digital Platform Inquiry" concerning the impact of digital platforms (Facebook and Google) on competition in the advertising and media markets. The ACCC has flagged numerous concerns about the market power and expected dominance of digital tycoons including the issues of bargaining settlement between digital tycoons and Australian advertising and media enterprises, harm to consumers, hitting the broader economy such as online content accuracy, privacy of data, and online copyright infringement.

\section{Theoretical Perspective and Literature Review}

The literature review reveals the fact that in redressing the problems against the theme of dominance and abusive conduct of corporations in the market is usually addressed by Commission (EU) by adopting the effects based approach. But the nature of conduct of market dominated corporations taking undue advantage of that effects based doctrine. If the conduct of any firm is commercially injurious or restricting competition then why it should not be considered as Per Se illegal from the very beginning rather to wait for the consequences of its damages to other business entities. Although the term Object has not been defined properly but it should be analyzed by the enforcement authorities by taking into account its possible effects priorly within the relevant market. For example, if a dominant firm acquires any running business startup within the already dominated market which may resultantly enhance or strengthen the acquirer firm position and the competition may be abolished or reduced between the potential rivals within that market. The Article 102 of TFEU prohibits certain forms of unilateral market behavior but nothing conclusive explanation about object based practices has cemented and provided list of certain abusive practices is not exhaustive (Podszun and Kreifels, 2016). As the article applies only to abusive conduct which may be exclusionary, exploitative, discriminatory depending upon the effects not on the object based practices. The abuse may be by object of undertakings. The term undertaking is not defined in Article 102 of TFEU and what kind of practices would be declared as Per Se illegal under the said article being abusive practice is also lacking. The concept of undertaking and abuse is generally applicable under Article 102 to all commercial entities but there should be clear demarcation between undertaking and dominant undertaking, unfair business practices and abusive business practices and the nature of penalties also. It is also an axiomatic fact that judicial interpretations of article 102 has been made differently so this gap between objective theory or practice and effects theory or practice still required understandable justifications from 
the policy makers concerning to promote pure competition, economic efficiency and judicial compliance. Before 1998, the annulment of Commission's decisions were very rare but after the establishment of The European General Court the conventional wisdom of the Commission's decisions is subject to judicial review now. Therefore, the insertion of the new provisions about the notion of dominance and abusive practices, Per Se illegal practices with detailed list and effects based practices might be the call of time. The digital platforms should be regulated in accordance with the emerging needs focusing the business perspective and privacy issues for accelerating growth (Kerber, 2016: Lianos, 2019: Hylton, 2019; Coyle, 2019). Recently it has pointed out in the report that the regulators could define the market nature of digital platforms either it's the same concept of market as traditional market structure or it may differ? (Haucap, 2019; Komninos and Truli, 2020; Ghosh, 2020).

\section{Research Design}

The methodology is based on data collected from the European Union (EU), the Federal Trade Commission (USA), the Department of Justice (USA), the Australian Competition and Consumer Commission (ACCC), and other websites on abuse by large companies, as well as case law, where Regulators impose heavy penalties for violations of competition laws and their impact on distorting competitive markets. Furthermore, analyzed traditional antitrust methods, heoretical and practical methodologies to fill the literature gap between theory and practice. The legal research is conducted by method according to the character and typical of the jurisprudence which differs from the social sciences and natural science. The research method includes the approach the determination of legal materials and critical analysis of the material contained therein legal process to think that is explorative, inquiry and interpretation.

The research method uses normative research that is a research referring to the legal norms contained in competition/antitrust law. The problem approach used in the research is an approach of legislation (statute approach). Furthermore, sources of law in the research consist of primary source of law, secondary source of law and tertiary source of law. The primary source of law is competition law. Secondary source of law covers literature, scholarly writings such as textbooks, journals, papers, dictionaries, and articles contained in the print and electronic media. The analysis is carried out and poured in the form of descriptive analysis that contains activities of explaining, studying, systematizing, interpreting and evaluating. The next step is a theoretical analysis of the ingredients of the law to find, understand and explain in depth the competition law.

\section{Recent Developments About Dominance And Digital Data Utilization}

The USA Department of Justice's commences the investigation against big tech corporations with the focus of their possibility that tech firms might use data which they have attained from consumers in the context to block rival competitors from the market they manage. The Assistant Attorney General MAKAN DELRAHIM, said" that our focus is on "THE POTENTIAL ABUSE OF DATA BY ONLINE PLATFORMS, including search industry and social media". He further said that they are trying to identify the other harmful practices of Google and Facebook could go on. In addition, he explored that these companies have large amount of data which they might use to restrain the other competitors from challenging the market because these companies have been found in repeated habitual conduct in the context of abuse of data utilization and dominant position."

The United States Federal Trade Commission established the task force with the focus to monitor competitive process in US digital markets. In the United Kingdom the Digital Competition Expert Panel (DCEP) headed by Jason Furman suggested in his report published earlier in March 2019, the creation of a unit with the remit to use all the frameworks and tools to strengthen competition and consumer choice in digital markets. And must be supported by the new legislation to ensure its effective enforcement.

The Canadian Competition Bureau (CCB) has also bring the necessity to create and accelerate the key role of Chief digital enforcement officer with the ambition to commence 15 digital platforms investigations in 2020. The Danish Competition and Consumer Authority (DCACA) in May 2019, announced the creation of a Centre for Digital Platforms with aim to concrete the enforcement of its existing competition provisions concerning digital platforms.

The next presidential candidate in USA Elizabeth Warren is also publically announced that Big tech firms, their abusive control over the data and their dominance will remain her chief priorities and she drafting a distinguished 
piece of legislation that would go beyond the proposals of breaking up or blocking deals among big firms and would exert strong Governmental control over largest corporations. The antitrust experts and those who support that bill say it takes unprecedented steps to incorporate new provisions to regulate the big companies conduct. The tentative legislation named the Anti-Monopoly and Competition Restoration Act. But here the question will remain intact weather the proposed enactment will have the retrospective effect or not against the already pending inquiries and investigations of big firms. It has become her slogan now to bring some structural changes in the American's economy.

\section{Google As Monopoly}

Google is USA based search and advertisement firm which earns its maximum revenue through ad's and online search and has been find by the European Regulators consecutively due to its anti-competitive conduct. Google.com is the most visited site on the planet. Google's statement of purpose is "to compose the world's data and make it all around open and helpful".

Google is without a doubt one of the biggest and most clear monopolies on the planet. Truth be told, the organization hoards a few distinct markets, including search and promoting. Bing, its nearest search rival, has only 2 percent of the market - scarcely a noteworthy danger to Google's 90 percent. Google likewise controls around 60 percent of the worldwide promoting income on the web. One of the essential reasons littler promoters can't contend is on the grounds that they don't have the client information Google has.

In 2011, the Federal Trade Commission explored antitrust objections against Google. Howl, Microsoft, Amazon, eBay, Expedia and Yahoo all said their business had endured because of Google's anticompetitive conduct. A private update spilled to the Wall Street Journal uncovers FTC staff had prescribed recording an antitrust suit against the organization, taking note of that "Google is in the extraordinary position of having the option to 'represent the moment of truth any online business' and has fortified its monopolies over inquiry and search publicizing through anticompetitive methods and thwarted contenders' and would-be contenders' capacity to challenge those monopolies."

The organization spent more cash on political campaigning in 2017 than some other company. It has no under 25 distinctive campaigning firms taking a shot at its sake. Google is additionally subsidizing 300 exchange affiliations, think tanks and other significant gatherings with impact over government strategy. As indicated by Reback, Google has "a seat at the table in each exchange. They think about improvements that we never at any point find out about. In this way, their impact, from my point of view, is exceptionally, hard to challenge.

On base of above discoveries, it tends to be considered there is a huge hazard that dependent on a conventionalist and an Austrian financial aspects point of view, Google is a monopoly. The end is that Google is a monopoly, under both a conventional understanding and dependent on various articles perusing, future government intercession is unquestionably a hazard for Google and its speculators.

\section{Digital platforms and consumers}

The consumers overall benefit from the free services offered by the digital platforms but only rare consumers have been fully informed of, understand and efficaciously control the scope of data collected and the bargain they are entering into with digital platforms when they sign up for or use their services. There is a substantial disconnect between how consumers think about their data should be treated and how it is actually treated. The lack of both consumer protection and effective regulatory laws concerning data collection has enabled monopolistic data practices. Resultantly the weak transparent and control strategies undermines consumer ability to select a product that best meets their privacy priorities. The another obstacle in the enforcement of privacy laws is the individual consumers inability to bring direct actions for breaches of their privacy that cause financial harm.

\section{Ongoing inquiries/investigations against Google or Facebook}

1. Atlanta based ad-tech company inform Inc, is filed a lawsuit against Google for anti-competitive behavior by alleging that Google effectively put inform out of the business. The suit is filed on November 25, 2019 in the federal court of Atlanta with the charge of that Google used its monopolistic control over the mobile operating 
system and internet search to exclude competitors from the ad market. The inform inc, company further said that it generates more than US \$100Million revenue through ad-tech solutions between 2014-2016, and Google intentionally put the rivals out of business.

2. The Music Website Genius Media sued Google for publishing lifted song lyrics which according to them amounts to anti-competitive behavior that causes harm to the Music Company. The suit has been filed in state court in Brooklyn, NEW YORK. The music company seeks US\$50 Million as compensation from Lyric Find and Google. The media company claims unusual traffic to its site where the company placed hard-to-decipher lyrics to hip-hop songs and many other pop hits, suddenly began dropping because Google started publishing lyrics on its own platform and few of them were lifted directly from their site.

3. The Advertising platform Criteo filed a written complaint before the French Competition Authority (FCA) against Facebook with the allegation that Facebook severely effecting of online advertising industry. The complainant said it is not for the first time that Facebook has infringed the competition provisions, last year the small advertisers group had also files suit in the Federal Court of California with the accusations of that Facebook has engaged in unfair business practice by disseminating wrong metrics that potentially overestimated the value of time users were spending watching video ads.

4. The Australian Competition and Consumer Commission (ACCC) raised various concerns about the expected market power and its abusive use of digital platforms keeping in view the privacy matter, media and advertising companies, consumer protection, and online copyright infringement.

5. The United Kingdom's competition (CMA) watchdog has initiated the proceedings to conduct an inquiry against Google for the acquisition of data analytics firm Looker for US\$2.6 billion. The Competition authority said they have "reasonable grounds "to commence the inquiry that Google designed to roll Looker into its parent company Alphabet, rather to keep it separate. The Google has already got approvals for the same kind of merger/acquisitions from the United States and Austria.

6. FORTNITE developer Epic is suing Apple and Google after both pulled Epic's hit game from their app stores over direct-payment disputes.

7. Social media giant Facebook has come in for heavy criticism as part of a US congressional hearing into the dominance of online tech platforms, being accused of "copy, acquire and kill' tactics as part of its history in acquiring smaller businesses.

8. The Senate Judiciary Committee's antitrust panel (USA) will hold a hearing in September to discuss Google's dominance in online advertising.

9. Google will face a full scale EU antitrust investigation into its planned $\$ 2.1$ billion bid for fitness tracker maker FITBIT unless it offers concessions to address competition concerns.

10. The Australian Competition and Consumer Commission (ACCC) has delayed its ruling on Google's proposed takeover of fitness wearable manufacturer, FITBIT, by another four months.

\section{Hypothesis}

Hypothesis 1; Is the competition law enforcement week or completed?

Hypothesis 2; Why the abuse of dominant position in the market has not been treated aggressively?"

Hypothesis 3; Does the effects based doctrine is efficacious to encounter the abusive practices?" Hypothesis 4; Is the repeated habitual practice of abusive conduct be tackled by imposing heavy fines?"

Hypothesis 5; "Does the difference of interpretation by European Union and European General Court about the provisions of abuse of dominant position create obstacles in the enforcement of competition laws? 
Hypothesis 6; Are the big corporations taking the advantage of lengthy and time taking enforcement process?

Hypothesis 7; "Do the jurisdictional matters affect the proper enforcement of legal provisions concerning abusive market conduct?"

Hypothesis 8; Does the digital data for commercial utilization affect the small and medium enterprises?

Hypothesis 9; Does the article 102 of TFEU has taken into consideration for per se illegal practices or not?"

\section{Model Specification and Results}

To test the hypotheses, statistical package for social sciences (SPSS) was used. Hypotheses were tested using T-test, Pearson product moment correlation analysis, descriptive and frequency analysis of various cases decided by the different competition law enforcement authorities within the European jurisdictions. The data of the cases were taken from the respective official websites of the authorities concerned. Following were the results of these statistical analyses:

\subsection{Hypothesis 1: T-Test}

It was questioned in the hypothesis: "Is the competition law enforcement week or completed?" Table 1.1, 1.2, 1.3 show the results:

\section{Table 1.1}

T-Test Analysis of cases decided by competition authorities.

\begin{tabular}{|c|c|c|c|c|}
\hline & $\mathrm{N}$ & Mean & Std. Deviation & Std. Error Mean \\
\hline $\begin{array}{c}\text { Cases by Competition } \\
\text { Authorities }\end{array}$ & 16 & 1.1250 & .34157 & .08539 \\
Cases by Other Authorities & 10 & 1.4000 & .51640 & .16330 \\
\hline
\end{tabular}

\section{Table 1.2}

Comparative analysis between competition authorities.

\begin{tabular}{|l|c|c|c|c|c|c|}
\hline & \multicolumn{6}{|c|}{ Test Value = 0 } \\
\cline { 2 - 7 } & & & & & \multicolumn{2}{c|}{$\begin{array}{c}\text { 95\% Confidence Interval of } \\
\text { the Difference }\end{array}$} \\
\cline { 4 - 8 } & $\mathrm{T}$ & $\mathrm{df}$ & $\begin{array}{c}\text { Sig. (2- } \\
\text { tailed) }\end{array}$ & $\begin{array}{c}\text { Mean } \\
\text { Difference }\end{array}$ & Lower & Upper \\
\hline $\begin{array}{l}\text { Cases by Competition } \\
\text { Authorities }\end{array}$ & 13.175 & 15 & .000 & 1.12500 & .9430 & 1.3070 \\
$\begin{array}{l}\text { Cases by Other } \\
\text { Authorities }\end{array}$ & 8.573 & 9 & .000 & 1.40000 & 1.0306 & 1.7694 \\
\hline
\end{tabular}

Tables 1.1, 1.2 show the result of One Sample T-test analysis. There were two comparison groups from which the cases were taken; Competitive Authorities and Other Authorities. The value of significance sig $=0.00$ show that there is significant difference between the cases that were taken by Competitive Authorities and those of Other Authorities in terms of their law enforcement. The t-value shows that cases taken by Competitive Authorities had more completed law enforcement.

\subsubsection{Frequency Table}


Table 1.3

Frequency Analysis of compliance of decisions by Competition Authorities

Cases by Competition Authorities

\begin{tabular}{|cc|c|c|c|c|}
\hline & & & & \\
& & Frequency & Percent & Valid Percent & Cumulative Percent \\
\hline Valid & Completed & 14 & 87.5 & 87.5 & 87.5 \\
& Weak & 2 & 12.5 & 12.5 & 100.0 \\
& Total & 16 & 100.0 & 100.0 & \\
& \multicolumn{2}{|r}{} &
\end{tabular}

\section{Table 1.4}

Frequency Analysis of compliance of decisions by other Authorities

Cases by Other Authorities

\begin{tabular}{|cc|c|c|c|c|}
\hline & & & & \\
& & Frequency & Percent & Valid Percent & Cumulative Percent \\
\hline Valid & Completed & 6 & 60.0 & 60.0 & 60.0 \\
& Weak & 4 & 40.0 & 40.0 & 100.0 \\
& Total & 10 & 100.5 & 100.0 & \\
& & & & \\
\hline
\end{tabular}

Tables 1.3, 1.4 show the result of Frequency analysis conducted to find out the number of completed and weak cases by authorities. The table show that out of $\mathrm{N}=16$ cases taken by Competitive authorities, $87.5 \%$ cases were completed in terms of law enforcement and $12.5 \%$ were weak. While out of $\mathrm{N}=10$ cases taken by Other Authorities, $60.0 \%$ cases were completed and $40.0 \%$ were weak in terms of law enforcement. This shows that cases taken by Competitive Authorities were more completed in terms of law enforcement as compared to cases taken by Other Authorities.

\subsection{Hypothesis 2:}

It was questioned in the hypothesis: "Why the abuse of dominant position in the market has not been treated aggressively?" Table 2.1 show the results:

\subsubsection{Frequency Table}

\section{Table 2.1}

Frequency analysis of abusive practices of digital firms Abuse of Dominance Authorities

\begin{tabular}{|c|c|c|c|c|c|}
\hline & & Frequency & Percent & Valid Percent & Cumulative Percent \\
\hline \multirow[t]{3}{*}{ Valid } & Competition & 7 & 43.8 & 70.0 & 70.0 \\
\hline & Other Authorities & 3 & 18.8 & 30.0 & 100.0 \\
\hline & Total & 10 & 62.5 & 100.0 & \\
\hline
\end{tabular}


Table 2.2

Frequency analysis of decisions taken by authorities

Abuse of Dominance Decision

\begin{tabular}{|cc|c|c|c|c|}
\hline & & & & \\
& & Frequency & Percent & Valid Percent & Cumulative Percent \\
\hline Valid & Penalty & 5 & 31.2 & 50.0 & 50.0 \\
& Unresolved & 5 & 31.2 & 50.0 & 100.0 \\
& Total & 10 & 62.5 & 100.0 & \\
\hline
\end{tabular}

Table 2.3

Correlations analyses between the decisions of two different authorities.

\begin{tabular}{|ll|c|c|}
\hline & & $\begin{array}{c}\text { Abuse of Dominance } \\
\text { Authorities }\end{array}$ & $\begin{array}{c}\text { Abuse of Dominance } \\
\text { Decision }\end{array}$ \\
\hline $\begin{array}{l}\text { Abuse of Dominance } \\
\text { Authorities }\end{array}$ & $\begin{array}{l}\text { Pearson Correlation } \\
\text { Sig. (2-tailed) }\end{array}$ & 1 & $-655^{*}$ \\
& $\mathrm{~N}$ & 10 & .040 \\
\hline $\begin{array}{l}\text { Abuse of Dominance } \\
\text { Decision }\end{array}$ & Pearson Correlation & $-655^{*}$ & 10 \\
& Sig. (2-tailed) & .040 & 1 \\
& $\mathrm{~N}$ & 10 & 10 \\
\hline
\end{tabular}

*. Correlation is significant at the 0.05 level (2-tailed).

It was assumed that the unfair treatment of abusive practices in the market by digital firms could be because of difference of authorities which address the case. To test this assumption, Pearson Product Moment Correlation analysis was used. The results in tables 2.1, 2.2, 2.3 show that different Authorities have a significant correlation with type of decision taken for each case with the value of Sig=0.40. The negative value of correlation= -.655 shows that more the cases taken by Competitive Authorities, less are the chances of those cases to be treated aggressively. . This shows that Competition watchdogs seems reluctant in enforcing their decisions aggressively.

\subsection{Hypothesis 3:}

\subsubsection{Correlation}

It was questioned in the hypothesis: "Does the effects based doctrine is trenchant to encounter the abusive practices?" Table 3.1 show the results:

\section{Tables 3.1}

Correlation analysis between abusive conduct and awarded penalty.

\begin{tabular}{|c|c|c|}
\hline & Type of Case & Type of Penalty \\
\hline Type of Case & 1 & $.491^{*}$ \\
\hline
\end{tabular}




\begin{tabular}{|c|c|c|c|}
\hline & $\begin{array}{c}\text { Sig. (2-tailed) } \\
\text { N }\end{array}$ & 26 & $\begin{array}{l}.011 \\
26\end{array}$ \\
\hline Type of Penalty & $\begin{array}{c}\text { Pearson Correlation } \\
\text { Sig. (2-tailed) } \\
\text { N }\end{array}$ & $\begin{array}{c}.491^{*} \\
.011 \\
26\end{array}$ & 1 \\
\hline
\end{tabular}

*. Correlation is significant at the 0.05 level (2-tailed).

For this analysis, only the cases involved in abusive market practices with Effect based doctrine were considered and their correlation with type of penalty of for each case was assessed. The results in table 3.1 show that there is positive significant correlation between types of cases and the types of Penalty for each case with the value of significance= 0.11 and value of correlation $=.491$. This reflects that the effects based doctrine is potent to encounter the abusive practices.

\subsection{Hypothesis 4:}

It was questioned in the hypothesis: "Is the repeated habitual practice of abusive conduct be tackled by imposing heavy fines?" Table 4.1 show the results:

\section{Table 4.1}

Correlation analysis between continual abusive practices and imposing heavy fines

\begin{tabular}{|c|c|c|c|}
\hline & & Type of Case & Fine Based Penalty \\
\hline \multirow[t]{3}{*}{ Type of Case } & Pearson Correlation & 1 & -.285 \\
\hline & Sig. (2-tailed) & & .158 \\
\hline & $\mathrm{N}$ & 26 & 26 \\
\hline \multirow[t]{3}{*}{ Fine Based Penalty } & Pearson Correlation & -.285 & 1 \\
\hline & Sig. (2-tailed) & .158 & \\
\hline & $\mathrm{N}$ & 26 & 26 \\
\hline
\end{tabular}

To conduct this analysis, two types of cases were considered; the ones with habitual abusive practices and the other ones with rare practice. It was investigated whether these two types of cases had correlation with the Fine based penalty for each case or not. The cases with habitual practice were given higher value and the cases with rare practice were given lower value. The results in Table 4.1 showed that there is negative correlation between types of cases and Fine Based Penalty with the value of correlation $=-.285$ which reflect that the repeated habitual practice of abuse has not tackled by imposing heavy fines.

\subsection{Hypothesis 5:}

It was questioned in the hypothesis: "Does the difference of interpretation by European Union and European General Court about the provisions of abuse of dominant position create obstacles in the enforcement of competition laws?" Table 5.1 show the results:

\section{Table 5.1}

Correlation analysis regarding interpretation of laws between European Commission and European General Court 


\begin{tabular}{|cc|c|c|}
\hline & & Court Type & $\begin{array}{c}\text { Enforcement of } \\
\text { Competition Law }\end{array}$ \\
\hline Court Type & Pearson Correlation & 1 & -.053 \\
& Sig. (2-tailed) & & .796 \\
& $\mathrm{~N}$ & 26 & 26 \\
\hline Enforcement of Competition Law & Pearson Correlation & -.053 & 1 \\
& Sig. (2-tailed) & .796 & 26 \\
$\mathrm{~N}$ & 26 & \\
& \multicolumn{2}{|r|}{}
\end{tabular}

For this analysis, the cases were sorted into the two types of court that they had been handled from; European Union (here in referred as European Commission) and European General Court and then Correlation between both the types were tested with Enforcement of Competition law for each case. Table 5.1 shows the result and it was found out that there was no significant correlation between the two types of court and Enforcement of Competition law for each case as the value of significance is .796 which is $>0.05$. This reflects that the difference of interpretation by European Union (European Commission) and European General Court about the provisions of abuse of dominant position does not create obstacles in the enforcement of competition laws.

\subsection{Hypothesis 6:}

It was questioned in the hypothesis: "Are the big corporations taking the advantage of lengthy and time taking enforcement process?" Table 6.1 show the results:

\section{Table 6.1}

Correlation Analysis between Big Enterprises and prolonged enforcement process of judgments

\begin{tabular}{|cc|c|c|}
\hline & & Size of Corporation & $\begin{array}{c}\text { Immediacy of } \\
\text { Penalty }\end{array}$ \\
\hline Size of Corporation & Pearson Correlation & 1 & .000 \\
& Sig. (2-tailed) & & 1.000 \\
$\mathrm{~N}$ & 15 & 15 \\
\hline Immediacy of Penalty & Pearson Correlation & .000 & 1 \\
& Sig. (2-tailed) & 1.000 & 15 \\
$\mathrm{~N}$ & 15 & \\
\hline
\end{tabular}

To test this hypothesis, Corporations were sorted according to their size and their correlation with Immediacy of Penalty for each case was checked. Table 6.1 show the result and it was found out that there was no significant correlation between different Sizes of Corporation; Large, Medium and Small, and the Immediacy or Delay in penalty for cases as the value of significance is 1.00 which is $>0.05$. This shows that big corporations are not taking the advantage of lengthy and time taking enforcement process. 


\subsection{Hypothesis 7:}

It was questioned in the hypothesis: "Do the jurisdictional matters affect the proper enforcement of legal provisions concerning abusive market conduct?" Table 7.1 show the results:

\section{Table 7.1}

Correlation analysis of the jurisdiction of enforcers and enforcement of statutes beyond jurisdiction

\begin{tabular}{|cc|c|c|}
\hline & $\begin{array}{c}\text { Jurisdictional } \\
\text { Matter involved }\end{array}$ & $\begin{array}{c}\text { Immediacy of } \\
\text { Penalty }\end{array}$ \\
\hline Jurisdictional Matter Involved & Pearson Correlation & 1 & .068 \\
Sig. (2-tailed) & $\mathrm{N}$ & .810 \\
\hline Immediacy of Penalty & Pearson Correlation & .068 & 1 \\
\hline Sig. (2-tailed) & .810 & 15 \\
\hline
\end{tabular}

For this analysis, cases were sorted according to involvement of jurisdictional matters and their correlation with immediacy of penalty for each case was tested. It was found out that there is no significant correlation between involvement of jurisdictional matters and immediacy of penalty as the value of significance is .810 which is $>0.05$. This shows that jurisdictional matters do not affect the proper enforcement of legal provisions concerning abusive market conduct.

\subsection{Hypothesis 8:}

It was questioned in the hypothesis: "Does the digital data for commercial utilization affect the small and medium enterprises?" Table 8.1 show the results:

\section{Table 8.1}

Frequency Analysis between Digital Firms possessing large customer data and Small \& Medium enterprises

Digital Data Cases

\begin{tabular}{|c|c|c|c|c|}
\hline & Frequency & Percent & Valid Percent & $\begin{array}{c}\text { Cumulative } \\
\text { Percent }\end{array}$ \\
\hline Valid $\quad$ Affecting Small/Medium \\
Enterprise & 10 & 34.5 & 66.7 & 66.7 \\
Not Affecting Small/Medium \\
$\begin{array}{c}\text { Enterprise } \\
\text { Total }\end{array}$ & 5 & 17.2 & 33.3 & 100.0 \\
& 15 & 51.7 & 100.0 &
\end{tabular}


Digital Data Cases

\begin{tabular}{|c|c|c|c|c|}
\hline & Frequency & Percent & Valid Percent & $\begin{array}{c}\text { Cumulative } \\
\text { Percent }\end{array}$ \\
\hline Valid $\begin{array}{c}\text { Affecting Small/Medium } \\
\text { Enterprise }\end{array}$ & 10 & 34.5 & 66.7 & 66.7 \\
Not Affecting Small/Medium \\
Enterprise \\
Total
\end{tabular}

To test this hypothesis, Frequency analysis was conducted and the results showed that there are more cases that are being affected by the digital data $(34.5 \%)$ than the cases which are not being affected by the digit data (17.2\%).

\subsection{Hypothesis 9:}

It was questioned in the hypothesis; "Does the article 102 of TFEU has taken into consideration for per se illegal practices or not?"

Among the $\mathrm{N}=26$ cases, there were $n=11$ cases related to per se illegal practice. The data showed that only 2 of those cases were dealt with consideration of article 102 of TFEU which means that in only $18 \%$ cases of per se illegal practice, article 102 of TEFU was taken into consideration.

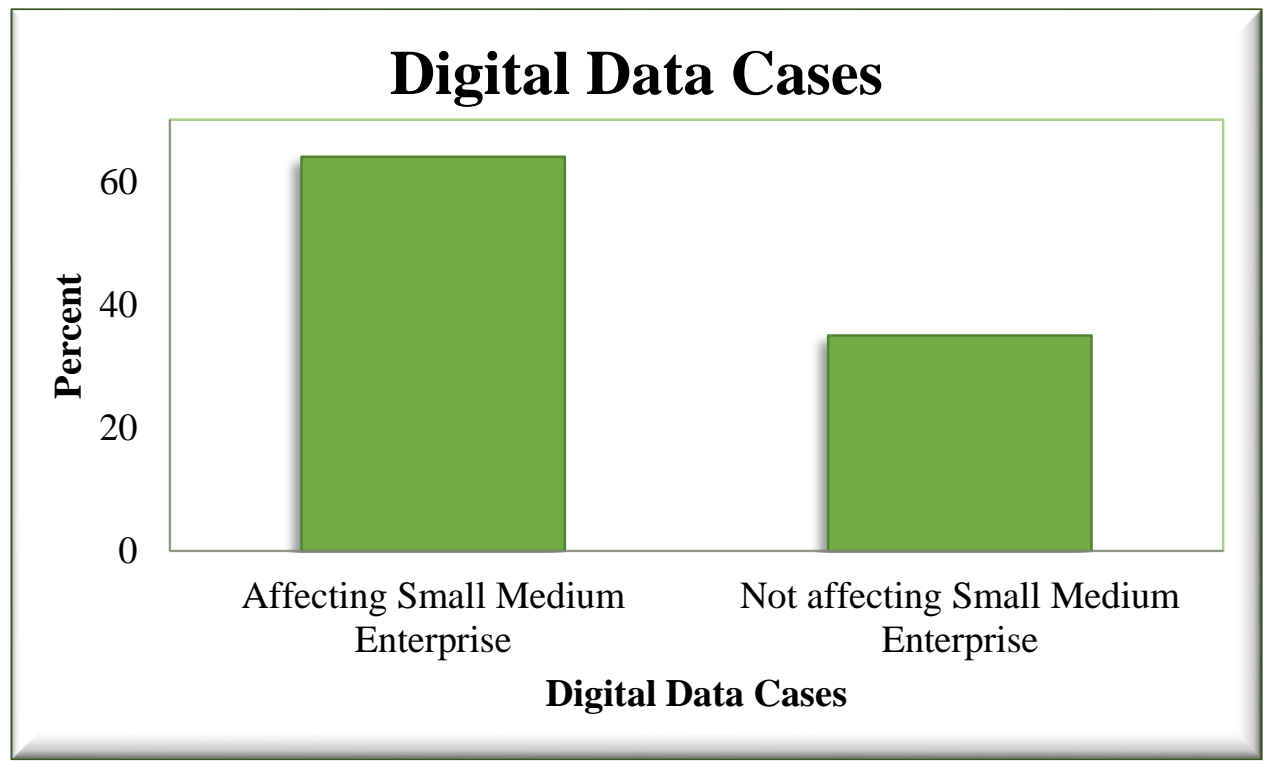

Fig 1. Comparative analysis between data rich companies and S\&ME

The above graph illustrates that the digital data for commercial utilization affect small and medium enterprises.

\section{Recommendation and Conclusion}

The digital platforms are providing significant benefits to consumers but the opaque operations of digital platforms and their presence in interrelated markets mean it is difficult to examine precisely what standard of behavior and 
corporate conduct these digital platforms are meeting.

1. The establishment of special regional digital platforms units.

2. The advance global agencies must share their experience and learnings with the less developed enforcement authorities.

3. The new specific corporate governance code of conduct for digital companies be made out with mandatory cross border enforcement at regional level.

4. The disinformation and deceptive marketing practices on digital platforms be considered as" Financial Business Harm" with distinctive remedies for injurious enterprises.

5. The new legislation be required particularly with the issue of digital platforms collection, use and disclosure of user data.

6. It is not about the data practices of digital platforms only but many online businesses including telecommunications, airlines, news media companies, auto mobile industry, financial institutions, and data brokers are also seems involved in such practices such as using click-wrap agreements to gain bundled consent which is ambiguous and fulsome disclosures providing less control to consumers over their personal information be regularized strictly and consent of consumers be taken in accordance with the laws relevant to address the point with its true spirit. The consent must not be coercive rather it could be reciprocal.

7. The data rich companies should be restricted in swiping the new competitors in the market like Google and Facebook have purloin almost all its rivals within the market in the name of Mergers and Acquisitions (M\&A).

It is vital to note that the governments around the world recognized the emerging role digital platform performs in our daily collective and individual lives and looking more pro-active in anticipating the anti-competitive practices.

\section{References}

Choi, Y. S. (2018). Competition Law of Exploitative Abuse-The MEO Case in the EU and Implications for Korea. Law Journal, 62, 303-326.

Choi. E., (2017). The study on competition restriction analysis of rebates by market dominant undertakings-focused on Intel case, Kyungpook National university law journal, 45, 177-212.

Coyle, D. (2019). Practical competition policy implications of digital platforms. Antitrust Law Journal, 82(3), 835860.

Dongwon, L., (2018), antitrust regulation trends of big data trading in china, journal of law research, 34(4), $297-319$. Gary Reback," you should be outraged at Google's anti-competitive behavior. The Washington post, july,7, 2017. Ghosh, S. (2020). Competition in digital markets. In Research Handbook on Intellectual Property and Digital Technol Haucap, j.(2019). Competition and Competition Policy in a Data-Driven Economy. Intereconomics, 54(4), 201-208. https://konkurransetilsynet.no/?lang=en\&s=taxi+case +2017

Hylton, K. N. (2019). Digital Platforms and Antitrust Law. Boston Univ. School of Law, Law and Economics Research Paper No, (19-8).

Kemp, K. (2019). Concealed Data Practices and Competition Law: Why Privacy Matters. UNSW Law Research Paper, (19-53).

Kerber, W. (2016). Digital markets, data, and privacy: competition law, consumer law and data protection. Journal of Intellectual Property Law \& Practice, 11(11), 856-866.

Kerber, W. (2019). Updating Competition Policy for the Digital Economy? An Analysis of Recent Reports in Germany, UK, EU, and Australia. An Analysis of Recent Reports in Germany, UK, EU, and Australia (September 14, 2019).

Koenig, C. (2018). Form, Effects, or Both?-The More Economic Approach and the European Commission's Decision in Google Search. The More Economic Approach and the European Commission's Decision in 
Google Search (April 1, 2018), 44(5), 680-693.

Komninos, A., \& Truli, E. N. (2020). FIDE XXIX Hague Congress 2020, EU Competition Law and the Digital Economy, National Report• Greece. National Report• Greece (September 1, 2019).

Lianos, I. (2019). Blockchain Competition-Gaining Competitive Advantage in the Digital Economy: Competition Law Implications. Oxford University Press.

Mattiuzzo, M. (2019). Algorithms and Big Data: Considerations on Algorithmic Governance and Its Consequences for Antitrust Analysis. Revista De Economia Contemporânea, 23(2), 6-15.

Mzungus, H. (2019). A study on the relation between market dominant position and abuse, the journal of legal studies, 27(2), 149-167.

NIE, YINGZHI\&CHEN, PENG. (2019). big data and abuse of dominance in business sector, journal of environmental protection and ecology, 20(2), 1001-1009.

NUCCIO, M., \& GUERZONI, M. (2018). Big data: Hell, or heaven? Digital platforms and market power in the datadriven economy. Competition \& Change, 23(3), 312-328.

Pfeiffer, R. A. C. (2019). Digital Economy, Big Data and Competition Law. Market and Competition Law Review, 3(1), 53-89.

Pinar Akman (2017), The theory of abuse in Google search; A positive and normative assessment under EU competition law, journal of law, technology and policy, volume 3,301.

Podszun, R., \& Kreifels, S. (2016). Digital platforms and competition law. J. Eur. Consumer \& Mkt. L., 5, 33.

See the NCA's decision V2011-2 Tine v NCA, page 81, Retrieved December 15, 2019, available athttps://konkurransetilsynet.no/norwegian-competition-authority/?lang=en.

Šobot, S. F. (2018). A New Approach to Rebates after Intel Case. LeXonomica, 10(2), 103-118.

Supreme Cartel Court in Fachverband Reiseburos Vs Lufthansa, 12, July, 2018 available at https://www.bwb.gv.at/en/ 